\title{
Distribution of aquatic insects in urban headwater streams
}

\author{
Distribuição de insetos aquáticos em riachos urbanos
}

Luiz Ubiratan Hepp ${ }^{1}$, Rozane Maria Restello ${ }^{1}$, Silvia Vendruscolo Milesi², Cristiane Biasi ${ }^{3}$ and Joseline Molozzi ${ }^{4}$

${ }^{1}$ Programa de Pós-graduação em Ecologia, Universidade Regional Integrada do Alto Uruguai e das Missões - URI, Av. Sete de Setembro, 1621, CEP 99700-000, Erechim, RS, Brazil e-mail: lhepp@uricer.edu.br; rrozane@uri.com.br

${ }^{2}$ Programa de Pós-graduação em Ecologia, Universidade Federal do Rio Grande do Sul - UFRGS,

Av. Bento Gonçalves, 9500, CP 15007, CEP 91501-970, Porto Alegre, RS, Brazil

e-mail: silvia_milesi@yahoo.com.br

${ }^{3}$ Programa de Pós-graduação em Biodiversidade Animal, Departamento de Biologia, Centro de Ciências Naturais e Exatas, Universidade Federal de Santa Maria - UFSM, Faixa de Camobi, Km 09, prédio 17, sala 1104, CEP 97105-900, Santa Maria, RS, Brazil

e-mail: crisbiasi@yahoo.com.br

${ }^{4}$ Laboratório de Limnologia, Departamento de Biologia Geral, Instituto de Ciências Biológicas, Universidade Estadual da Paraíba - UEPB, Rua Baraúnas, 352, Bairro Universitário, CEP 58429-500, Campina Grande, PB, Brazil e-mail: jmolozzi@gmail.com

\begin{abstract}
Aims: The objective of this study was to evaluate the effects of urban environments on the distribution and occurrence of aquatic Ephemeroptera, Plecoptera and Trichoptera (EPT) insects in six urban subtropical streams; Methods: Organisms were collected with a Surber sampler in 2005 and 2006, over two hydrological cycles. We analyzed abundance values, taxonomic richness, Shannon-Wiener diversity and Pielou's evenness. A principal components analysis (PCA) was performed to evaluate the environmental variability of streams. A canonical correspondence analysis (CCA) was performed to evaluate the possible effects of environmental variables; Results: The PCA ordered the streams according to their quality, and Suzana and Nadau streams had higher concentrations of nutrients. The Baetidae (Ephemeroptera) was the family with the highest number of genera (18). Perissophlebiodes Savage, 1983, and Americabaetis Kluge, 1992, were the most common genera. Anacroneuria Klapálek, 1909, was the most abundant Pleocoptera, and Smicridea McLachlan, 1871, was the dominant Trichoptera genus. In the CCA, $\mathrm{pH}$, electrical conductivity and stream velocity were positively correlated with axis 1 , whereas dissolved oxygen was negatively correlated with axis 1; Conclusions: Our results show that the distribution of EPT in urban streams is affected by changes in water physicochemical characteristics. However, these changes are not sufficiently severe to cause the elimination of EPT.
\end{abstract}

Keywords: anthropogenic effects, multiple stressors, Ephemeroptera, Plecoptera, Trichoptera, environmental variables.

Resumo: Objetivos: O objetivo deste estudo foi avaliar os efeitos da urbanização sobre a ocorrência e distribuição de insetos aquáticos das ordens Ephemeroptera, Plecoptera e Trichoptera (EPT) em seis riachos subtropicais; Métodos: Os organismos foram coletados com um amostrador Surber, durante os anos 2005 e 2006, abrangendo dois ciclos hidrológicos. Foram analisados os valores de abundância, riqueza taxonômica, diversidade Shannon-Wiener e equitabilidade de Pielou. Uma Análise de Componentes Principais (ACP) foi aplicada para avaliar a variabilidade ambiental dos riachos. Uma Análise de Correspondência Canônica (ACC) foi realizada para avaliar os possíveis efeitos das variáveis ambientais sobre os organismos; Resultados: A ACP ordenou os riachos de acordo com sua qualidade, sendo que os riachos Suzana e Nadua apresentaram maiores concentraçôes de nutrientes. Baetidae (Ephemeroptera) foi a família com maior número de gêneros, 18. Perissophlebiodes Savage, 1983 e Americabaetis Kluge, 1992 foram os gêneros mais frequentes. Anacroneuria Klapálek, 1909 foi o mais abundante dentre os plecópteros coletados e Smicridea Mclachlan, 1871 foi dominante para Trichoptera. A ACC demonstrou que as variáveis $\mathrm{pH}$, condutividade elétrica e velocidade de correnteza foram positivamente correlacionadas ao $1^{\circ}$ eixo, enquanto que oxigênio dissolvido foi negativamente correlacionadas o eixo 1; Conclusôes: Os resultados mostram que a distribuição dos insetos aquáticos é afetada por alterações físicas e químicas causadas por atividades urbanas. No entanto, os níveis de perturbação não são suficientemente severos para causar a eliminação de EPT.

Palavras-chave: efeitos antropogênicos, estressores múltiplos, Ephemeroptera, Plecoptera, Trichoptera, variáveis ambientais. 


\section{Introduction}

In river networks, headwater streams comprise more than three quarters of the total length of the channel in the watershed (Clarke et al., 2008). Certain urban centers are undergoing very fast and uncontrolled growth due to population increases, but the basic structure of the cities often cannot support such growth. Many cities have no waste treatment systems, and organic matter is directly introduced into aquatic environments (Hepp et al., 2010). Wastewater discharges and vegetation removal have the potential to affect water quality and aquatic biodiversity (Milesi et al., 2008). The ecological consequences of organic matter input and riparian vegetation removal include reductions in habitat diversity and niche availability, impairment of stream function parameters and changes in species composition (Sensolo et al., 2012). Previous studies in the Alto Uruguai region (Rio Grande do Sul, Brazil) showed that headwaters are under strong pressure from human activities, particularly urbanization (Milesi et al., 2008; Hepp and Santos, 2009; Hepp et al., 2010).

The distribution patterns of aquatic organisms are controlled by substrate, temperature, geomorphologic and biological interactions (Baptista et al., 2001; Silveira et al., 2006), riparian vegetation and seasonality (Bispo et al., 2006), food availability (Gage et al., 2004), microhabitats, habitat heterogeneity (Crisci-Bispo et al., 2007a), physical and chemical variables (Milesi et al., 2008) and land use (Molozzi et al., 2007; Hepp and Santos, 2009; Hepp et al., 2010; Sensolo et al., 2012). It is important to understand how changes in the above factors affect the distribution of invertebrate assemblages in low-order streams because this information can be used in biomonitoring and restoration of degraded environments (Peeters et al., 2004; Clarke et al., 2008).

The family richness and abundance of Ephemeroptera, Plecoptera and Trichoptera (EPT) have been used in environmental quality assessments because most of these taxa are sensitive to several stressful conditions (Marques et al., 1999; Crisci-Bispo et al., 2007). Urban and suburban streams stressed by human activities should therefore exhibit differential distributions of aquatic insects. In this study, we investigated how urbanization affects the occurrence and distribution of Ephemeroptera, Plecoptera and Trichoptera aquatic insects in low-order streams in a subtropical area. Given the importance of environmental quality to the maintenance of aquatic insect assemblages, we hypothesized that these taxa might have been eliminated from impacted streams because they are known to be very intolerant to pollution, particularly increases in organic matter. However, the levels of contaminants must be very high to produce severe effects on the occurrence and distribution of Ephemeroptera, Plecoptera and Trichoptera.

\section{Material and Methods}

\subsection{Study area}

The study was conducted in Erechim, which is located in the northern region of Rio Grande do Sul ( $27^{\circ} 37^{\prime} 54^{\prime \prime} \mathrm{S}$ and $\left.52^{\circ} 16^{\prime} 52^{\prime \prime} \mathrm{W}\right)$. The city is located at $768 \mathrm{~m}$ above sea level and has a subtropical climate with an average annual temperature of $18.7^{\circ} \mathrm{C}$. The average annual rainfall exceeds $1800 \mathrm{~mm}$ (Cassol and Piran, 1975). Along the Uruguay River and its tributaries, the vegetation is characterized by a mixture of subtropical forest and Araucaria forest (Budke et al., 2010), featuring the following species in particular: Araucaria angustifolia (Bertol.) Kuntze, Apuleia leiocarpa (Vogel) J.F. Macbr., Nectandra megapotamica (Spreng.) Mez, Cupania vernalis Cambess., Ocotea sp. (Leyser et al., 2009).

\subsection{Aquatic insect sampling and environmental data}

To determine the distribution of EPT taxa, we selected six first-order streams near the urban perimeter of Erechim $(-100,000$ inhabitants; Figure 1). Four samplings were performed in August 2005, November 2005, February 2006 and April 2006. Biological samples were collected with a Surber sampler (mesh: $0.25 \mathrm{~mm}$, area: $0.09 \mathrm{~m}^{2}$ ). Within a stretch approximately $15 \mathrm{~m}$ in length, ten sub-samples were collected approximately $1 \mathrm{~m}$ apart from a mixture of different substrate types (rock, litter and sand). The material was fixed in situ with $10 \%$ formalin and later identified to the genus level using taxonomic keys by Froehlich (1984), Fernandez and Dominguez (2001) and Pes et al. (2005). We measured the following environmental variables at all sampling sites: flow, water temperature, dissolved oxygen, electrical conductivity, $\mathrm{pH}$, biochemical oxygen demand (BOD), nitrate and phosphorus. The analyses were conducted following the procedures recommended in APHA (1998).

\subsection{Data analysis}

The organismal abundance and taxonomic richness were estimated for each sample. We 

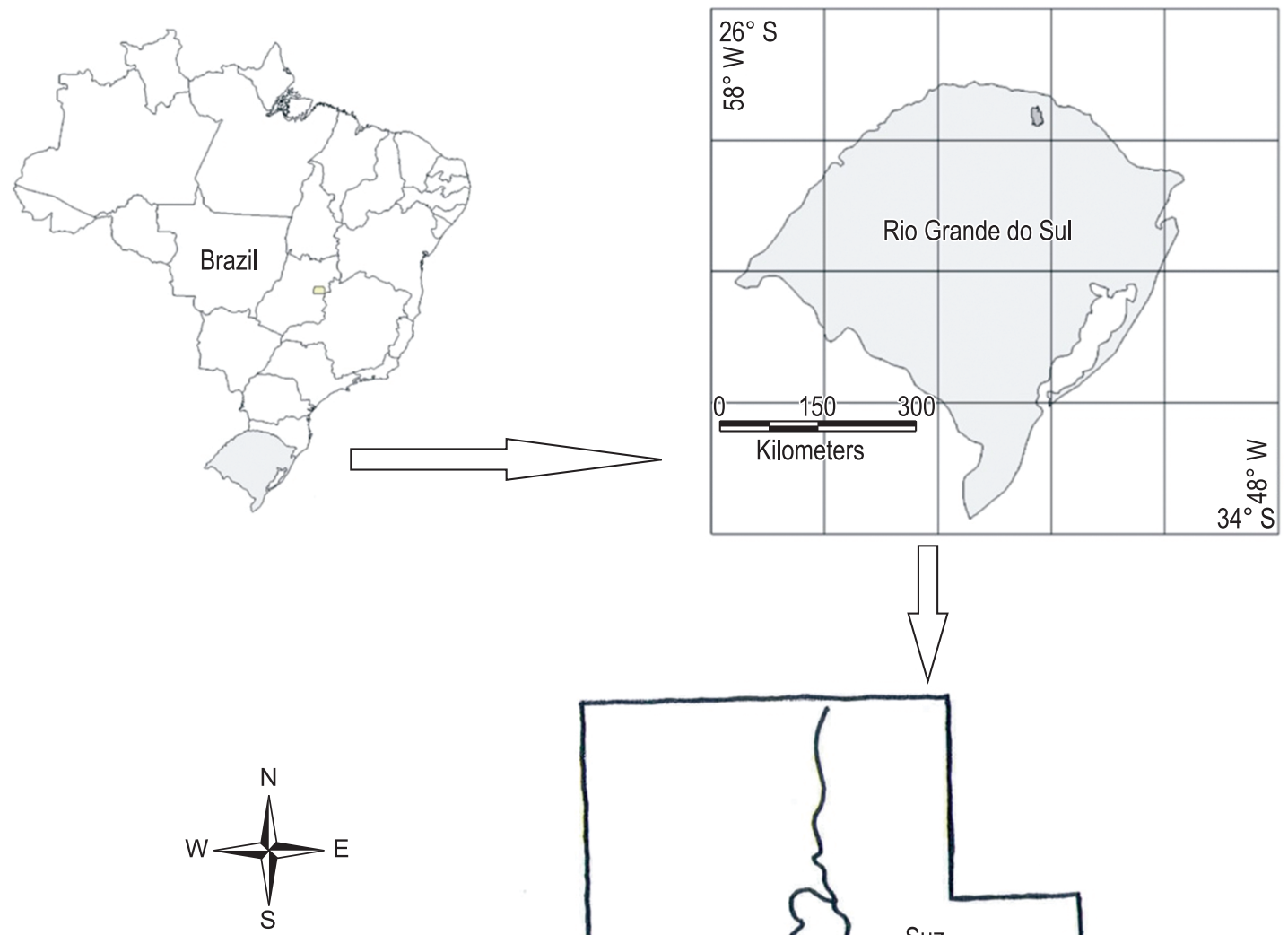

Streams:

Nad: Nadau

Dou: Dourado

Suz: Suzana

Lig: Ligeiro

Lignho: Ligeirinho

Le: Leãozinho
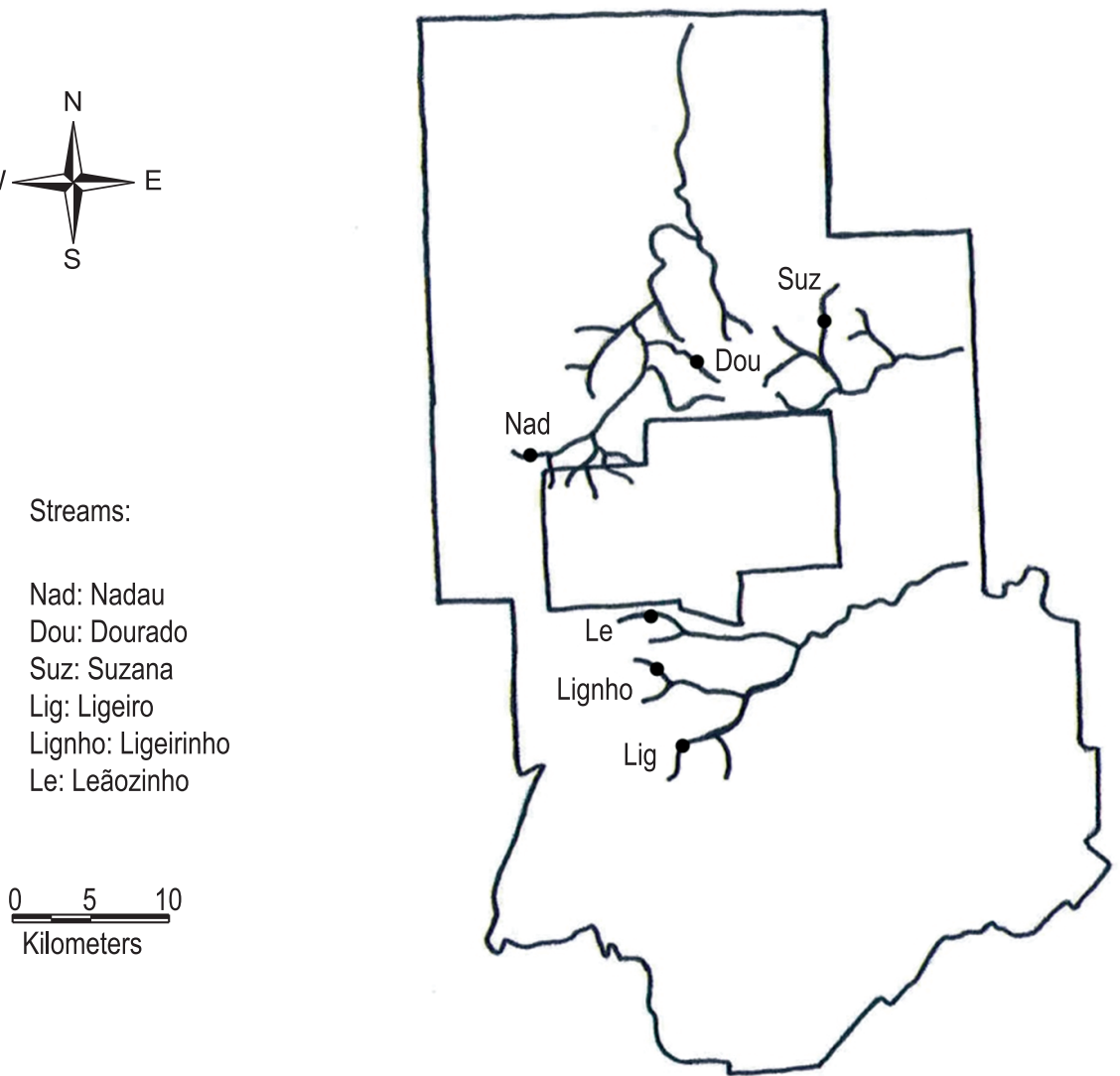

Figure 1. Geographical location Erechim, RS, and distribution of the urban streams studied.

calculated Shannon-Wiener diversity (Shannon and Weaver, 1963) and Pielou's evenness (Pielou, 1969). We performed a principal components analysis (PCA) to evaluate the ordination of the streams with respect to the environmental variables. For this analysis, we used environmental data standardized to a 0 to 1 range. The standardization was performed separately for each variable. We subtracted the minimum value of each variable and then divided each observed value by the maximum value of the variable. To evaluate the influence of environmental variables on insect distributions, we performed a canonical correspondence analysis (CCA) using an array of biological abundance data transformed into $\log (x+1)$. The second array used for the CCA was composed of environmental 
data. Analyses were conducted using the "vegan" package (Oksanen et al., 2011) in R software ( $R$ Core Team, 2011).

\section{Results}

The measured environmental conditions were similar across the six sites throughout the entire study period. The mean electrical conductivity in the Nadau stream was the highest, with values up to $85 \mu \mathrm{S} \mathrm{cm}^{-1}$. In general, the streams consisted of oxygenated waters $\left(>4.9 \mathrm{mg} \mathrm{L}^{-1}\right)$, ranging from slightly acidic (6.4) to neutral (7.1) (Table 1). The
BOD values were higher in the Ligeirinho and Nadau streams; nitrate levels were higher in the Ligeiro, Ligeirinho and Suzana streams; and phosphorus was higher in the Nadau and Suzana streams (Table 1). The two first principal components of the PCA of environmental data explained $80.1 \%$ of the total variation $(\mathrm{PC} 1=53.9 \%$; $\mathrm{PC} 2=26.2 \%)$. The $\mathrm{PCA}$ showed a gradient of organic contamination (BOD, nitrate and phosphorus) in PC1 (Figure 2).

A total of 909 aquatic insects were collected, consisting of $75 \%$ Trichoptera, 19\% Ephemeroptera and 6\% Plecoptera. We identified 13 genera and

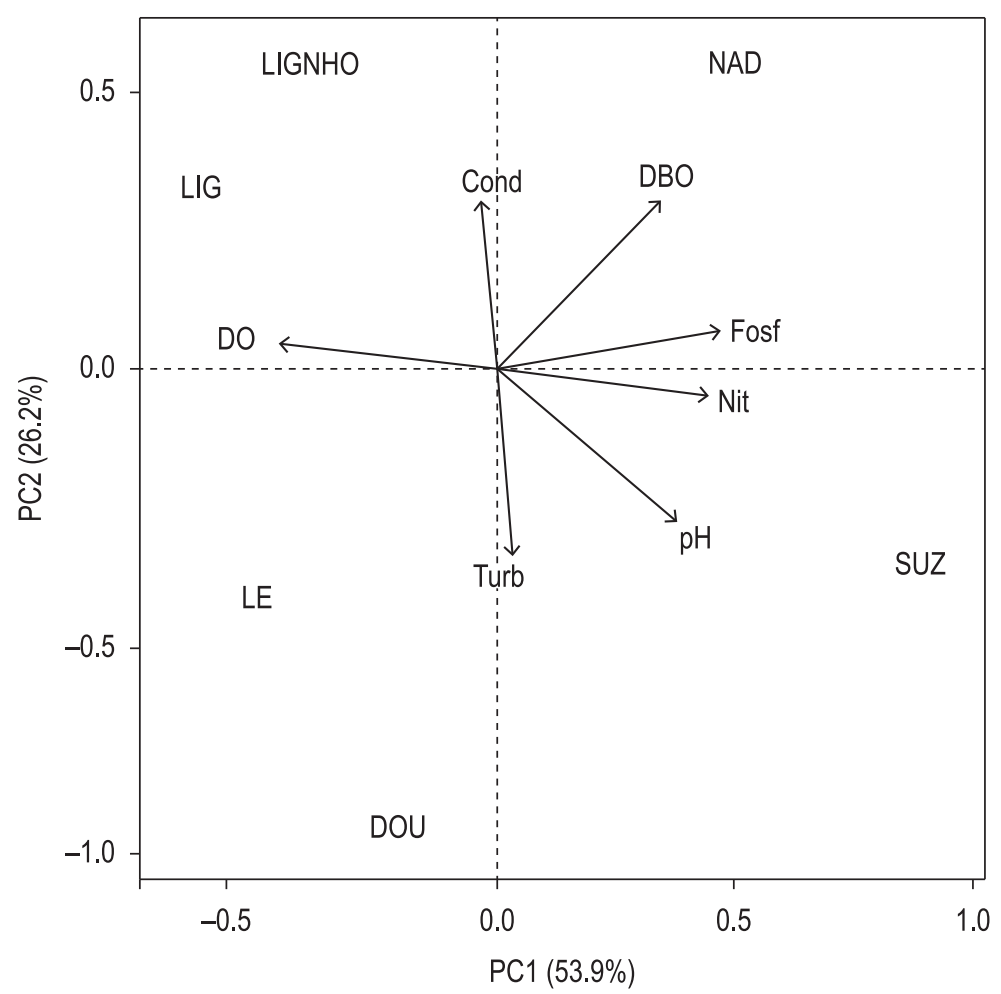

Figure 2. Biplot diagram of Principal Component Analysis of urban streams sites in Erechim city different seasons, during the studied period: $\mathrm{LIG}=$ Ligeiro, $\mathrm{LIGNHO}=$ Ligeirinho, $\mathrm{LE}=$ Leãozinho, NAD = Nadau, DOU = Dourado, SUZ = Suzana. Cond = conductivity; DO = dissolved oxygen; Turb = Turbidity; Nit = Nitrate; Fosf = Phosphorus; $\mathrm{DBO}=$ Biochemical oxygen demand.

Table 1. Mean values $( \pm S D)$ of environmental variables in the urban streams in the Erechim city.

\begin{tabular}{lcccccc}
\hline \multirow{2}{*}{ Variables } & \multicolumn{5}{c}{ Streams } \\
\cline { 2 - 6 } & Ligeiro & Ligeirinho & Leãozinho & Nadau & Dourado & Suzana \\
\hline Geographical coordinates & $27^{\circ} 43^{\prime} 30^{\prime \prime} \mathrm{S}$ & $27^{\circ} 41^{\prime} 09^{\prime \prime} \mathrm{S}$ & $27^{\circ} 40^{\prime} 22^{\prime \prime} \mathrm{S}$ & $27^{\circ} 37^{\prime} 15^{\prime \prime} \mathrm{S}$ & $27^{\circ} 36^{\prime} 47^{\prime \prime} \mathrm{S}$ & $27^{\circ} 36^{\prime} 51^{\prime \prime} \mathrm{S}$ \\
& $52^{\circ} 12^{\prime} 47^{\prime \prime} \mathrm{W}$ & $52^{\circ} 15^{\prime} 04^{\prime \prime} \mathrm{W}$ & $52^{\circ} 15^{\prime} 48^{\prime \prime} \mathrm{W}$ & $52^{\circ} 16^{\prime} 29^{\prime \prime} \mathrm{W}$ & $52^{\circ} 17^{\prime} 08^{\prime \prime} \mathrm{W}$ & $52^{\circ} 13^{\prime} 54^{\prime \prime} \mathrm{W}$ \\
Flow $\left(\mathrm{m} \mathrm{s}^{-1}\right.$ ) & $0.38 \pm 0.21$ & $0.33 \pm 0.19$ & $0.18 \pm 0.11$ & $0.38 \pm 0.20$ & $0.39 \pm 0.20$ & $0.45 \pm 0.28$ \\
Water temperature $\left({ }^{\circ} \mathrm{C}\right)$ & $16.4 \pm 1.7$ & $15.9 \pm 2.3$ & $18.5 \pm 0.5$ & $19.6 \pm 3.7$ & $16.9 \pm 2.0$ & $21.1 \pm 3.0$ \\
Eletric conductivity $\left(\mu \mathrm{S} \mathrm{cm}^{-1}\right)$ & $65.8 \pm 9.6$ & $65.1 \pm 6.5$ & $50.8 \pm 17.5$ & $81.6 \pm 21.9$ & $45.9 \pm 6.9$ & $49.4 \pm 24.4$ \\
pH & $6.4 \pm 1.2$ & $6.5 \pm 1.2$ & $6.7 \pm 0.7$ & $6.9 \pm 0.9$ & $7.1 \pm 0.5$ & $7.1 \pm 0.3$ \\
Dissolved oxygen $\left(\mathrm{mg} \mathrm{L}^{-1}\right)$ & $7.7 \pm 0.8$ & $7.6 \pm 1.1$ & $6.9 \pm 0.5$ & $6.0 \pm 1.9$ & $7.4 \pm 1.2$ & $4.9 \pm 1.04$ \\
BOD $\left(\mathrm{mg} \mathrm{L}^{-1}\right)$ & $0.88 \pm 0.55$ & $2.13 \pm 3.62$ & $0.59 \pm 0.40$ & $2.62 \pm 1.74$ & $0.67 \pm 0.45$ & $1,97 \pm 0.44$ \\
Phosphorus $\left(\mathrm{mg} \mathrm{L}^{-1}\right)$ & $0.04 \pm 0.01$ & $0.02 \pm 0.02$ & $0.02 \pm 0.01$ & $0.10 \pm 0.06$ & $0.04 \pm 0.03$ & $0.12 \pm 0.02$ \\
Nitrate $\left(\mathrm{mg} \mathrm{L}^{-1}\right)$ & $0.68 \pm 0.19$ & $1.46 \pm 0.93$ & $1.38 \pm 0.71$ & $0.83 \pm 0.56$ & $0.74 \pm 0.26$ & $1.59 \pm 0.33$ \\
\hline
\end{tabular}




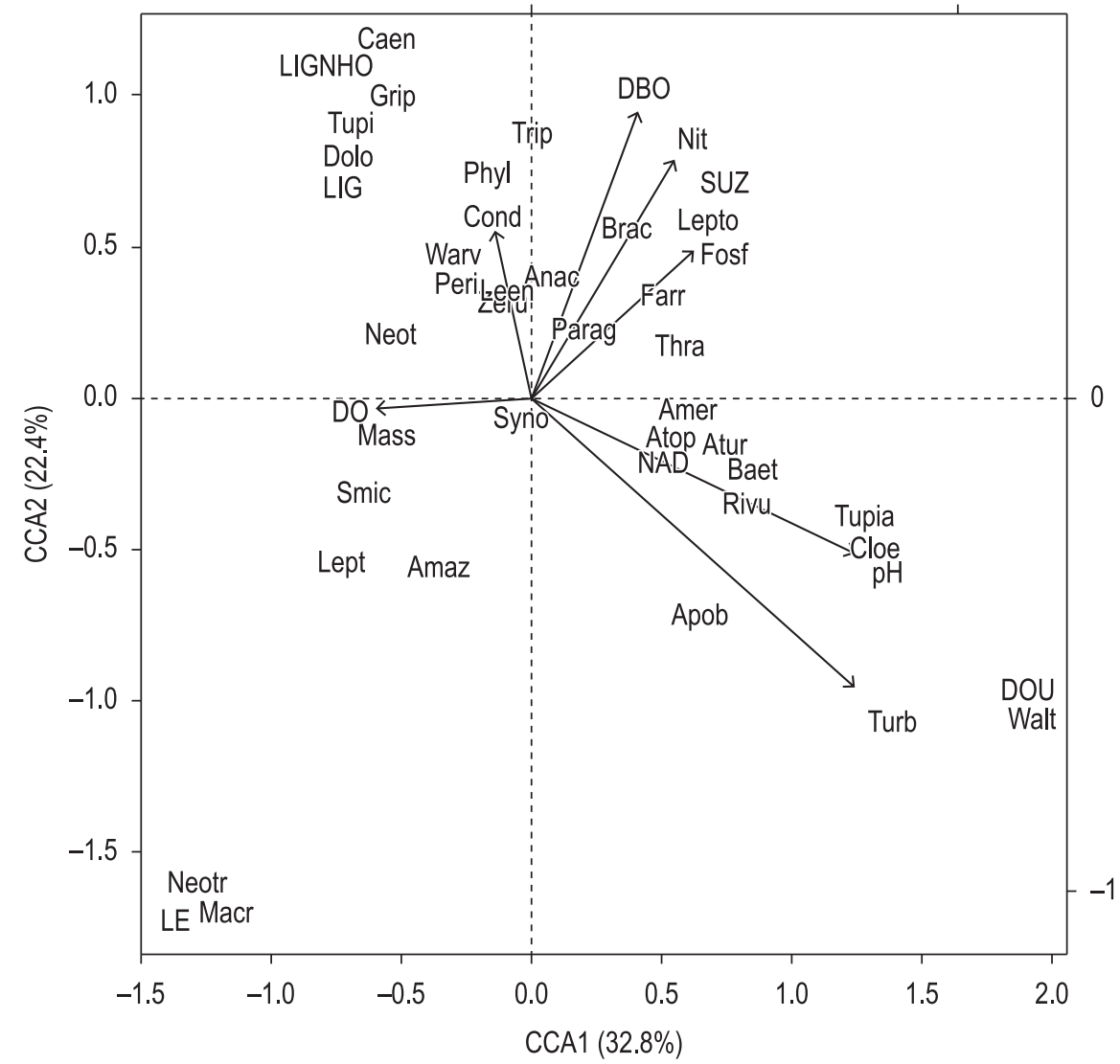

Figure 3. Canonical Correspondence Analyses using the community composition of EPT and environmental variables. Cond $=$ conductivity $; \mathrm{DO}=$ dissolved oxygen; Turb = Turbidity; Nit = Nitrate; Fosf = Phosphorus; $\mathrm{DBO}=$ Biochemical oxygen demand. $\mathrm{LIG}=$ Ligeiro; $\mathrm{LIGNHO}=$ Ligeirinho; $\mathrm{LE}=$ Leãozinho; NAD = Nadau; $\mathrm{DOU}=$ Dourado; $\mathrm{SUZ}=$ Suzana . amer $=$ Americabaetis $;$ anac $=$ Anacroneuria $;$ apob $=$ Apobaetis $;$ atur $=$ Aturbina $;$ baet $=$ Baetodes; cloe $=$ Cloeodes $;$ farr $=$ Farrodes $;$ grip $=$ Gripopterix $;$ lept $=$ Leptonema $;$ macr $=$ Macronema $;$ mori $=$ Moribaetis; neot $=$ Neotopsyche $;$ parag $=$ Paragripopteryx $;$ peri $=$ Perissophlebiodes $;$ phyl $=$ Phylloicus $;$ rivu $=$ Rivudiva $;$ smic $=$ Smicridea $;$ syno $=$ Synoestropsis; thra $=$ Thraulodes; tupia $=$ Tupiara .

seven families of Trichoptera, four families and 18 genera of Ephemeroptera and five genera and two families of Plecoptera (Table 2). Ephemeroptera and Trichoptera were collected at all streams, whereas Plecoptera occurred in just four of the six streams (absent from Leãozinho and Dourado).

The Baetidae (Ephemeroptera) family included 11 genera (Table 2), with Perissophlebiodes Savage, 1983, and Americabaetis Kluge, 1992, the two most frequent taxa in five streams. Anacroneuria Klapálek, 1909, was the most abundant genera of Plecoptera. Trichoptera was represented by 13 genera, with Smicridea McLachlan, 1871, the dominant group present in five sites (absent from Dourado).

Taxonomic richness was higher in the Nadau (23 genera), Suzana (17 genera), and Ligeirinho (15 genera) streams. The Shannon-Wiener diversity was highest in the Suzana and Nadau streams (3.67 bits and 3.66 bits, respectively) and lowest in the Leãozinho stream (1.09 bits). Evenness values were greater than 0.72 in all streams except Leãozinho, where the value was 0.33 (Table 2).

The first two axes of the CCA explained $55.2 \%$ of the total variation (axis $1=32.8 \%$; axis $2=22.4 \%$; Figure 3 ). The CCA showed that $\mathrm{pH}, \mathrm{BOD}$, nitrate and phosphorus levels were positively correlated with axis 1 , whereas dissolved oxygen and electrical conductivity were negatively correlated with axis 1 . Positive correlations with axis 1 were observed for Apobaetis Lugo-Ortiz and McCafferty, 1998, Thraulodes Ulmar, 1920, Farrodes Peters, 1971, Leptohyphodes Eaton, 1882, Rivudiva Lugo-Ortiz and McCafferty, 1998, Baetodes Needham and Murphy, 1924, Cloeodes Lugo-Ortiz and McCafferty, 1998, Americabaetis Kluge, 1992, Tupiara Salles, Lugo-Ortiz, Da-Silva and Francischetti, 2003, and Aturbina Lugo-Ortiz and McCafferty, 1996. Most of these genera were associated with the Nadau, Dourado and Susana streams, which showed slightly higher water 
Table 2. Abundance, taxonomic richness, Shannon-Wiener diversity and Pielou evenness of Ephemeroptera, Plecoptera and Trichoptera in the six urban streams in Erechim city. Lig $=$ Ligeiro, Lignho $=$ Ligeirinho, Le $=$ Leãozinho, $\mathrm{Nad}=$ Nadau, Dou $=$ Dourado, Suz $=$ Suzana .

\begin{tabular}{|c|c|c|c|c|c|c|}
\hline \multirow{2}{*}{ Taxa } & \multicolumn{6}{|c|}{ Streams } \\
\hline & Lig & Lignho & Le & $\mathrm{Nad}$ & Dou & Suz \\
\hline \multicolumn{7}{|l|}{ EPHEMEROPTERA } \\
\hline \multicolumn{7}{|l|}{ Baetidae } \\
\hline Rivudiva Lugo-Ortiz and McCafferty, 1998 & & & & 5 & 1 & \\
\hline Baetodes Needham and Murphy, 1924 & & & & 5 & 1 & 1 \\
\hline Apobaetis Lugo-Ortiz and McCafferty, 1998 & & & 2 & 3 & 4 & 1 \\
\hline Waltzoyphius McCafferty and Lugo-Ortiz, 1995 & & & & & 3 & \\
\hline Cloeodes Lugo-Ortiz and McCafferty 1998 & & & & 5 & 17 & 3 \\
\hline Americabaetis Kluge,1992 & & 3 & 1 & 12 & 6 & 9 \\
\hline Zelusia Lugo-Ortiz and McCafferty, 1998 & 1 & & & 1 & & \\
\hline Tupiara Salles, Lugo-Ortiz, Da-Silva and Francischetti, 2003 & & & & 3 & 11 & 4 \\
\hline Moribaetis Waltz and McCafferty, 1985 & & & & & & 4 \\
\hline Paracloedes Day, 1955 & & & & 1 & & \\
\hline Aturbina Lugo-Ortiz and McCafferty, 1996 & 1 & 1 & & 1 & 3 & \\
\hline \multicolumn{7}{|l|}{ Caenidae } \\
\hline Caenis Stephens, 1835 & & 6 & & & & \\
\hline \multicolumn{7}{|l|}{ Leptohyphidae } \\
\hline Leptohyphodes Eaton, 1882 & & & & & & 2 \\
\hline \multicolumn{7}{|l|}{ Leptophlebiidae } \\
\hline Thraulodes UImer, 1920 & & & & 6 & & 4 \\
\hline Farrodes Peters, 1971 & & 2 & & 4 & 1 & 9 \\
\hline Hagenulopsis Ulmer, 1920 & & & & & & 1 \\
\hline Perissophlebiodes Savage, 1983 & 7 & 5 & 2 & 4 & & 4 \\
\hline Massartella Lestage, 1930 & 2 & & 1 & 1 & & \\
\hline \multicolumn{7}{|l|}{ PLECOPTERA } \\
\hline \multicolumn{7}{|l|}{ Gripopterygidae } \\
\hline Gripopteryx Pictet, 1841 & 3 & 13 & & & & 1 \\
\hline Tupiperla Froehlich, 1969 & 2 & 1 & & & & \\
\hline Paragripopteryx Enderlein, 1909 & & 1 & & 3 & & \\
\hline \multicolumn{7}{|l|}{ Perlidae } \\
\hline Anacroneuria Klapálek, 1909 & 8 & 2 & & 16 & & 4 \\
\hline \multicolumn{7}{|l|}{ TRICHOPTERA } \\
\hline \multicolumn{7}{|l|}{ Calamoceratidae } \\
\hline Phylloicus Müller, 1880 & 6 & 9 & & 2 & & 6 \\
\hline \multicolumn{7}{|l|}{ Hydrobiosidae } \\
\hline Atopsyche Banks, 1905 & & & & 3 & & \\
\hline \multicolumn{7}{|l|}{ Hydropsychidae } \\
\hline Smicridea Mclachlan, 1871 & 28 & 28 & 323 & 28 & & 4 \\
\hline Leptonema Guérin, 1843 & 1 & 3 & 10 & 3 & & \\
\hline Synoestropsis Ulmer, 1905 & 31 & 48 & 38 & 33 & 25 & 13 \\
\hline Macronema Pictet, 1836 & & & 22 & & & \\
\hline \multicolumn{7}{|l|}{ Hydroptilidae } \\
\hline Neotrichia Morton, 1905 & & & 1 & & & \\
\hline \multicolumn{7}{|l|}{ Leptoceridae } \\
\hline Triplectides Kolenati, 1859 & & 1 & & & & 1 \\
\hline Neotopsyche Muller, 1879 & & 3 & 1 & 1 & & \\
\hline \multicolumn{7}{|l|}{ Philopotamidae } \\
\hline Wormaldia McLachlan, 1865 & 2 & & & 1 & & \\
\hline Chimarra Stephens, 1829 & & & & 3 & & \\
\hline Dolophilodes Ulmer, 1909 & 3 & & & & & \\
\hline Abundance & 95 & 126 & 401 & 144 & 71 & 71 \\
\hline Observed richness & 13 & 15 & 10 & 23 & 10 & 17 \\
\hline Shannon-Wiener diversity (bits) & 2.75 & 2.81 & 1.09 & 3.66 & 2.60 & 3.67 \\
\hline Pielou evenness & 0.74 & 0.72 & 0.33 & 0.80 & 0.78 & 0.90 \\
\hline
\end{tabular}


temperatures, $\mathrm{pH}$, and water flow than the others. Gripopterix Pictet, 1841, Tupiperla Froehlich, 1969, Scrimidea, Leptonema Guérin, 1843, Macronema Pictet, 1836, Neotopsyche Muller, 1879, Phylloicus, Wormaldia Mclachlan, 1865, Neotrichia Mocton, 1905, Perissophlebiodes, Massartella Lestage, 1930, Leentvaaria Demoulin, 1966, and Caenis Stephens, 1835 , were negatively correlated with axis 2 . These genera were associated with colder, more oxygenated waters, particularly in Ligeiro and Ligeirinho streams (Figure 3).

\section{Discussion}

The Nadau and Suzana streams were quite similar in terms of measured environmental variables. The Suzana stream was the site most affected by urbanization. The concentrations of nitrate and phosphorus revealed the existence of eutrophication process in this stream. Urban activities supply organic matter to water bodies and can promote the onset of eutrophication (König et al., 2008; Milesi et al., 2008; Hepp et al., 2010). Electrical conductivity is an important variable in streams impacted by urban activities (Salomoni et al., 2007). The input of organic matter leads to increased ion concentrations, which consequently increase conductivity values. Brigante and Espinola (2003) suggested that values above $100 \mu \mathrm{Sm}^{-1}$ are indicative of organic contamination. The conductivity values measured in the streams studied herein were below this threshold, indicating that the level of organic contamination is not very severe.

Ephemeroptera, Plecoptera and Trichoptera are recognized organismal bioindicators of water quality. We therefore expect that areas with high concentrations of polluting substances will present limited numbers of these organisms. Moreover, slight changes in water characteristics can affect the distribution of these insects. However, we observed several EPT genera in sites with higher than normal concentrations of nitrate and phosphorus for streams of the Alto Uruguay region. This result suggests two interpretations: (i) the studied streams, despite being located in urban districts, have not experienced the particular chemical changes that affect the occurrence of EPT; or (ii) some genera are more tolerant than reported in the literature.

The studied streams have very different environmental conditions, even when located in urban area drainage. This is not just environmental variation in physical and chemical water characteristics. The catchment land use is an important factor, as well as punctual and diffuse pollution sources. Admittedly, the urban perimeters in a timely manner and contribute negatively to water quality of streams (Hepp et al., 2010). Moreover, diffuse factor contribute negatively more subtly as water qualty (Sensolo et al. 2012). In this study, the presence of higher genus richness, especially tolerant organisms (e.g. Plecoptera) in places with poor water quality may be an indication that the current water quality is not being a limiting factor for the occurrence of organisms. Importantly, several factors (e.g. riparian vegetation, substrate, food availability) may influence the occurrence and diversity of EPT, not just the chemical characteristics of the waters (Crisci-Bispo et al., 2007b; Milesi et al., 2008; Hepp and Santos, 2009).

The EPT occurrence was somewhat restricted, particularly with regard to Plecoptera, which were only found in four streams. Moreover, the numbers of Plecoptera were low, accounting for only 6\% of the organisms collected. Roque et al. (2003) reported that the abundance and richness of EPT orders, especially Anacroneuria and Gripopteryx, were higher in areas associated with low human disturbance and high water flow, corroborating the results of this study. Buss and Salles (2007) commented that ephemeropterans, particularly Baetidae, also occur in disturbed sites. In the present study, we observed a correlation between the first axis and Americabaetis, Baetodes, Apobaetis and Cloeodes, indicating that these organisms were associated with sites with higher $\mathrm{pH}$ values and lower dissolved oxygen levels. Low values of dissolved oxygen indicate the presence of residue in urban streams (Salomoni et al., 2007). These effluents have a high chemical complexity, which ultimately affects other abiotic water variables and consequently changes the whole structure of aquatic communities.

Our results show that the occurrence and distribution of EPT in urban streams are affected by changes in the physical and chemical characteristics of the water. Among the variables studied, BOD, nitrate and phosphorus most markedly affected EPT distribution, particularly for Trichoptera and Plecoptera. Ephemeroptera, in contrast, showed little sensitivity to these variables. It is likely that the physical and chemical changes in water quality need to be more pronounced to generate extreme shifts in the occurrence of EPT. We found that variations in the chemical composition of urban stream waters were not sufficient to significantly damage the EPT fauna. Nevertheless, these results support the use of 
EPT in biomonitoring programs and corroborate previous reports that Ephemeroptera are not very sensitive to pollution and can be considered semitolerant organisms.

\section{Acknowledgments}

State Department of Environment and Ministry of Science and Technology of Rio Grande do Sul for financial support. We thank anonymous reviewers for their suggestions for improving the manuscript. RMR is supported by CNPq. CB received scholarships from $\mathrm{CNPq}$ and CAPES, respectively. JM receives a scholarship of CAPES. LUH is supported by FAPERGS and CNPq.

\section{References}

American Public Health Association - APHA. 1998. Standard methods for the examination of water and wastewater. 20th ed. Washington: APHA. 1180 p.

BAPTISTA, DF., BUSS, DF., DORVILLÉ, LFM. and NESSIMIAN, JL. 2001. Biodiversity and Habitat Preference of Aquatic Insects along the Longitudinal Gradient of the Macaé Rive Basin, Rio de Janeiro, Brazil. Revista Brasileira de Biologia, vol. 61, p. 1-17.

BISPO, PC., OLIVEIRA, LG., BINI, LM. and SOUSA, KG. 2006. Ephemeroptera, Plecoptera and Trichoptera assemblages from riffles in mountain streams of central Brazil: environmental factors influencing the distribution and abundance of immatures. Brazilian Journal of Biology, vol. 66, no. 2b, p. 611-622. PMid:16906293. http://dx.doi. org/10.1590/S1519-69842006000400005

BRIGANTE, J. and ESPÍNDOLA, ELG. 2003. Limnologia Fluvial: um estudo no Rio Mogi-Guaçu. São Carlos: RIMA Editora. 255 p.

BUDKE, JC., ALBERTI, MS., ZANARDI, C., BARATTO, C. and ZANIN, EM. 2010. Bamboo dieback and tree regeneration responses in a subtropical forest of South America. Forest Ecology and Management, vol. 260, p. 1345-1349. http:// dx.doi.org/10.1016/j.foreco.2010.07.028

BUSS, DF. and SALLES, FF. 2007. Using Baetidae species as biological indicators of environmental degradation in a Brazilian river basin. Environmental Monitoring and Assessment, vol. 130, p. 365-372. PMid:17106778. http://dx.doi.org/10.1007/ s10661-006-9403-6

CASSOL, E. and PIRAN, N. 1975. Formação geohistórica de Erechim. Perspectiva, vol. 1, no. 1, p. 5-54.

CLARKE, A., McNALLY, R., BOND, N. and LAKE, PS. 2008. Macroinvertebrate diversity in headwater streams: a review. Freshwater Biology, vol. 53, p. 1707-1721. http://dx.doi.org/10.1111/j.13652427.2008.02041.x
CRISCI-BISPO, VL., BISPO, PC. and FROEHLICH, CG. 2007a. Ephemeroptera, Plecoptera and Trichoptera assemblages in two Atlantic Rainforest streams, Southeastern Brazil. Revista Brasileira de Zoologia, vol. 24, no. 2, p. 312-318.

CRISCI-BISPO, VL., BISPO, PC. and FROELICH, CG. 2007b. Ephemeroptera, Plecoptera and Trichoptera assemblages in litter in a mountain stream of the Atlantic Rainforest from Southeastern Brazil. Revista Brasileira de Zoologia, vol. 24, p. 545-551.

FERNANDEZ, HR. and DOMINGUEZ, E. 2001. Guia para determinación de los artrópodos bentónicos Sudamericanos. Tucumán: UNT. 282 p.

FROEHLICH, CG. 1984. Brazilian Plecoptera 4. Nymphs of perlid genera from Southeastern Brazil. Annales de Limnologie, vol. 26, no. 1-2, p. 43-47.

GAGE, MS., SPIVAK, A. and PARADIRE, CJ. 2004. Effect of land use and disturbance on benthic insects in headwater streams draining small watershed north of Charlotte, NC. Southeastern Naturalist, vol. 3, no. 2, p. 345-358. http://dx.doi.org/10.1656/15287092(2004)003[0345:EOLUAD]2.0.CO;2

HEPP, LU. and SANTOS, S. 2009. Benthic communities of streams related to different land uses in a hydrographic basin in southern Brazil. Environmental Monitoring and Assessment, vol. 157, p. 305-318. PMid:18843547. http://dx.doi.org/10.1007/ s10661-008-0536-7

HEPP, LU., MILESI, SV., BIASI, C. and RESTELLO, RM. 2010. Effects agricultural and urban impacts on macroinvertebrates assemblages in streams (Rio Grande do Sul, Brazil). Zoologia, vol. 27, p. 106-113.

KÖNIG, R., SUZIN, CRH., RESTELLO, RM. and HEPP, LU. 2008. Qualidade das águas de riachos da regiāo norte do Rio Grande do Sul (Brasil) através de variáveis físicas, químicas e biológicas. Pan-American Journal of Aquatic Sciences, vol. 3, no. 1, p. 84-93.

LEYSER, G., VINISKI, M., DONIDA, AL., ZANIN, EM. and BUDKE, JC. 2009. Espectro de dispersão de um fragmento de transição entre Floresta Ombrófila Mista e Floresta Estacional na região do Alto Uruguai, Rio Grande do Sul, Brasil. Pesquisas Série Botânica, vol. 60, p. 355-366.

MARQUES, MGSM., FERREIRA, RL. and BARBOSA, FAR. 1999. A comunidade de Macroinvertebrados Aquáticos e características Limnológicas das Lagoas Carioca e da Barra, Parque Estadual do Rio Doce, MG. Revista Brasileira de Biologia, vol. 59, no. 2, p. 203-210. http://dx.doi.org/10.1590/S003471081999000200004

MILESI, SV., BIASI, C., RESTELLO, RM. and HEPP, LU. 2008. Efeito de metais Cobre $(\mathrm{Cu})$ e Zinco $(\mathrm{Zn})$ sobre a comunidade de macroinvertebrados bentônicos em riachos do sul do Brasil. Acta Scientiarum. Biological Sciences, vol. 30, p. 283-289. 
MOLOZZI, J., HEPP, LU. and DIAS, A. 2007. Influence of Rice crop on the benthic community in Itajaí Valley (Santa Catarina, Brazil). Acta Limnologica Brasiliensia, vol. 19, no. 4, p. 383-392.

OKSANEN, J., KINDT, R., LEGENDRE, P., O'HARA, RB. and STEVENS, MHH. 2011. Vegan: Community Ecology Package: R package. Available from: http://r- forger-projectorg/projects/vegan/

PEETERS, ETHM., GYLSTRA, R. and VOS, JH. 2004. Benthic macroinvertebrate community structure in relation to food and enviromnmental variables. Hydrobiologia, vol. 519, p. 103-115. http://dx.doi. org/10.1023/B:HYDR.0000026497.48827.70

PES, AMO., HAMADA, N. and NESSIMIAN, JL. 2005. Chaves de identificação de larvas para famílias e gêneros de Trichoptera (Insecta) da Amazônia Central, Brasil. Revista Brasileira de Entomologia, vol. 49, no. 2, p. 181-204. http://dx.doi. org/10.1590/S0085-56262005000200002

PIELOU, EC. 1969. An Introduction to Mathematical Ecology. New York: Wiley Interscience. 286 p.

R Core Team. 2011. R: A language and environment for statistical computing. Vienna: R Foundation for Statistical Computing. Available from: <http:// www.R-project.org/>.
ROQUE, FO., STRIXINO, ST., STRIXINO, G., AGOSTINHO, RC. and FOGO, JC. 2003. Benthic macroinvertebrates in streams of Jaraguá State Park (Southern Brazil) considering multiple spatial scales. Journal of Insect Conservation, vol. 7, p. 63-72. http:// dx.doi.org/10.1023/A:1025505323668

SALOMONI, SE., ROCHA, O. and LEITE, EH. 2007. Limnological characterization of Gravataí river, Rio Grande do Sul. Acta Limnologica Brasiliensia, vol. 19, no. 1, p. 1-14.

SENSOLO, D., HEPP, LU., DECIAN, V. and RESTELLO, RM. 2012. Influence of landscape on assemblages of Chironomidae in Neotropical streams. Annales de Limnologie - International Journal of Limnology, vol. 48, p. 391-400. http://dx.doi. org/10.1051/limn/2012031

SHANNON, CE. and WEAVER, W. 1963. The Mathematical Theory of Communication. Illinois: University of Illinois Press. 117 p.

SILVEIRA, MP., BUSS, DF., NESSIMIAN, JL. and BAPTISTA, DF. 2006. Spatial and temporal distribution of benthic macroinvertebrate in a southeastern Brazilian river. Brazilian Journal of Biology, vol. 66, p. 623-632. PMid:16906294. http:// dx.doi.org/10.1590/S1519-69842006000400006

Received: 09 January 2012 Accepted: 10 April 2013 